Volume 11 Number 2, April-June 2017: pp. 133-149

Copyright (c) 2017 FIAT JUSTISIA. Faculty of Law, Lampung

University, Bandarlampung, Lampung, Indonesia. ISSN:

1978-5186 | e-ISSN: 2477-6238.

Fiat Justisia is licensed under a Creative Commons Attribution 4.0

International License, which permits unrestricted use, distribution, and reproduction in any medium, provided the FATIUSTISA original work is properly cited.

\title{
The Urgency of Protection of Hand-Rolled Kretek as Handicraft Product of Geographical Indication of Kudus District
}

\author{
Toebagus Galang Windi Pratama \\ Faculty of Law, University of PGRI Semarang \\ toebagusgalang@upgris.ac.id
}

\begin{abstract}
Hand-rolled Kretek Protection as a Handicraft Product of Geographical Indication is an urgency because even though this product has taken $r$ deep roots in Indonesian's Culture, but because of the negative stigma of the danger of Cigarette made this product existence decreased over time, causing many small Hand-Kretek industries bankrupt and many Kretek-Roller Labourer Fired. The Study of Hand-Rolled Kretek as a Handicraft Product of Geographical Indication of Kudus District uses a Sociological Approach Method with Juridical-Empirical research method. The Primary data used in this research are Data Obtained from related people or Institution with the help of relevant literature, Documents and comparison to similar regulation from other countries as a secondary Data to find out whether Hand-Rolled Kretek is in accordance with product law provisions that can be a Geographical Indication Product of Handicraft or not and what implication that may occur. The result of the research shows that hand-rolled kretek can be a product of Geographical Indication because, regarding history, its distinguishing potential, and economic potential are sufficient, and are by the rules given, morality, religion and public order stated in Law No. 20 of 2016. The implications that arise can be seen both in the field of Economics such as increasing state income and employment, in the field of Social which can straighten the negative stigma of Hand-rolled kretek, and also in the field of Law where Hand-Rolled Kretek as a Geographical Indication Product of Handicraft can be used as a Reference for other industries to become a Geographical Indication products.
\end{abstract}


Keyword: Hand-Rolled Kretek, Geographical Indication, Handicraft Product, Kudus District.

\section{A. Introduction}

Kretek, that is Indonesian's Cigarette which consists of not only tobacco but also clove and a special flavor mixture may not need to be protected because its product that could even reach 332 Million cigarette pieces in 2013, ${ }^{1}$ not to mention the recent campaign to ban cigarette all over the world because it is unhealthy that also happen in Indonesia. Despite the controversy, Kretek is a savior to the state's Industry because it contributes to the nation's income in the form of excise. Kretek, despite its glorious production rate, has another side that needs to be noted. Among many variants of kretek, there are two major variants of kretek that is MachineRolled Kretek (Sigaret Kretek Mesin) and Hand-Rolled Kretek (Sigaret Kretek Tangan). Unlike Machine-Rolled Kretek that is more efficient and laborless, Hand-Rolled Kretek is, on the contrary, cost more labor which makes it less and less productive each year making many small hand-rolled kretek industries bankrupt not to mention that many Kretek-Roller Labourer that are fired due to the recess, therefore, it must be protected.

Some points that can be considered why a hand-rolled kretek can be registered as a product of geographical indication is, in addition to the unique shape of hand-rolled kretek (conical/tapered at the suction) that serves as a natural filter that cannot be imitated by machine, is how kretek has become so deep-rooted in the economy of Indonesian society as seen from the fact that a lot of resources of labor are siphoned to it and how much it contributes to foreign exchange, hand-rolled kretek are also deeply rooted in the national culture, as it can be seen in the kudus district, a district where kretek is first found (effectively, making it as a region suitable as geographical indication origin) in which also has a copyrighted-kretek creations dance. $^{2}$

Making Hand-rolled kretek as Geographical Indications is also legally possible because it is supported by the fact that Geographical indications in

\footnotetext{
${ }^{1}$ http://bisnis.liputan6.com/read/603799/ri-produksi-332-miliar-batang-rokok-tahun-ini Date Accessed 11/20/2017

${ }^{2}$ Badrudin, Academic Paper, (2016), p. 8. See also, DPR-RI, Academic Paper, RUU tentang Kebudayaan, 2016, p.64. The hand-Rolled Kretek are deeply rooted to the Indonesian culture, where kretek is unique in that the majority of Hand-Rolled Kretek production is produced through human hands, and its unique combination between Tobacco and cloves are only found in Indonesia. Tobacco as the main element in the manufacture of cigarettes is the result of the processing of endemic archipelago plants that can only exist in some areas in Indonesia. It had a huge difference to processed products of tobacco in other countries, such as cigars in Cuba and biddies in India.
} 
the form of handicrafts that is furniture-carve Jepara has been achieved, creating a possible outcome for other handicraft to be one too. ${ }^{3}$

The idea of hand-rolled Cigarettes as a geographical indication handicraft product will inevitably lead to controversy because it will contradict to the Article 56 paragraph (1) Points (a), ie geographical indications that may not be registered if it is in contrary to the legislation, morality, religion,ethics, and public order as there is Restrictive Regulation on Cigarettes ${ }^{4}$ in addition to as seen in point (b) of the same article states that if the product misleads the public regarding its reputation, quality, characteristics, source, the process of manufacture of goods and/or their use, it cannot be registered. This act's article is closely related to the fact that kretek or, Cigarette, in general, are not found in Indonesia but are first found in The United States, so their "originality" is questionable. ${ }^{5}$

Reflecting on the difficulties of the above difficulties, then the principal issue of whether the Hand-rolled kretek can be Geographical Indications or not, the matter need to be studied in depth because hand-rolled kretek is the spearhead of small and medium kretek industry, as no less than 4100 cigarette industry has gone out of business since 2009 because Kretek Cigarettes are already no-longer regarded as local wisdom by the government and a narrow viewpoint of the government that only looked kretek from its harmful medical terms. Whereas many countries are competing to register Geographical Indications for their tobacco processing such as Cuba and Turkey especially in the face of the increasingly tight economic competition, of course, the industry sector that has a large natural contribution should be noticed and supported. Therefore, the main subjects that will be discussed in this article are:

1. Can Hand-Rolled Kretek Product become Geographical Indication Product of Handicraft Of Kudus District?

2. What Implications may occur if Hand-Rolled Kretek Products In Kudus district can be Protected As Geographical Indications?

\footnotetext{
${ }^{3}$ Buku Persyaratan Indikasi Geografis Meubel Ukir Jepara, Pemkab Jepara, 2010.

${ }^{4}$ Indonesia's Government Regulation No 109 Year 2012 on the safety of Ingredients Containing Addictive Substances in the form of Tobacco Products for Health in Article 27 limiting Tobacco Products Advertisement will certainly become a polemic when Hand-rolled Kretek becomes Geographical Indication Product because in article 70 paragraph (2) of act Number 20 Year 2016 About Trademark and Geographical Indication requires the Government To foster and oversee commercialization and socialization of Geographical Indication Products.

${ }^{5}$ Ronald Hutapea, Why Rokok? Tembakau Dan Peradaban Manusia; Jakarta: Bee Media, (2013), p. 15.
} 


\section{B. Method}

The research method used in this research uses a Sociological Approach Method with Juridical-Normative research method. The specification of the research is Descriptive Analytical where the problem is solved by describing the state of the object of research at present, based on facts of what appears or as it is. The Primary data used in this research are Data Obtained from related people or Institution with the help of relevant literature, documents and comparison to similar regulation from other countries as a secondary Data to find out whether Hand-Rolled Kretek is in accordance with the product law provisions can be a Geographical Indication Product of Handicraft or not and what implication that may occur.

\section{Discussion}

\section{Hand-Rolled Kretek Product As Geographical Indication Product of Handicraft Of Kudus District}

\section{a. Why Hand-Rolled Kretek Needs to be Protected}

Despite all the negative stigma that are given to the Kretek as a variant of Cigarette, it doesn't hide the fact that kretek has stuck its root deep in to the culture of Indonesia as it can be seen from the high production of the kretek cigarettes in which means that kretek are still accepted in Indonesia's Society despite all the negative stigma that is given.

By the protection of hand-rolled kretek, there are several reasons Why Hand-Rolled Kretek Needs to be Protected. First, its uniqueness that is not present in other cigarettes. Many cigarettes that are made by machines can only produce tubular shapes, but in Hand-Rolled Kretek the shape is conical which the shape of the suction end is smaller than the other end making it a natural filter. The shape explained can be seen below:

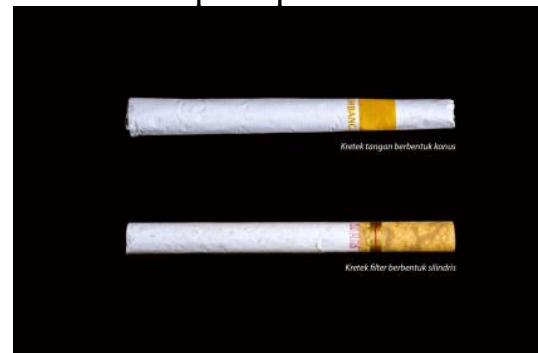

Picture 1: Hand-Rolled Kretek Shape Comparison ${ }^{6}$

\footnotetext{
${ }^{6} \mathrm{http} / / /$ bolehmerokok.com/mengkonsumsi-kretek-tangan-menjaga-penghidupan-banyakorang/ date accessed 11/20/2017
} 
The unique shape that cannot be created by machine is one factor that makes Hand-Rolled Kretek worth to be protected. Second, its deep-rooted place the in Indonesian's Culture and Economy. As it can be seen not only in its consumption Culture where it is used not only for consumption but also for a traditional ceremony where it is used as a Rokok Sajen ( Offerings to the gods). In Economy where many labors can be absorbed to the point of making it a specialty whether in its making the formula, rolling it, or tasting it. The existence of this is threatened by the ever tightened regulation that makes many of small hand-Rolled Kretek Industries bankrupt, and many laborers fired creating an economic downturn in contrast to Machine-Rolled Kretek that increases over time as seen below:

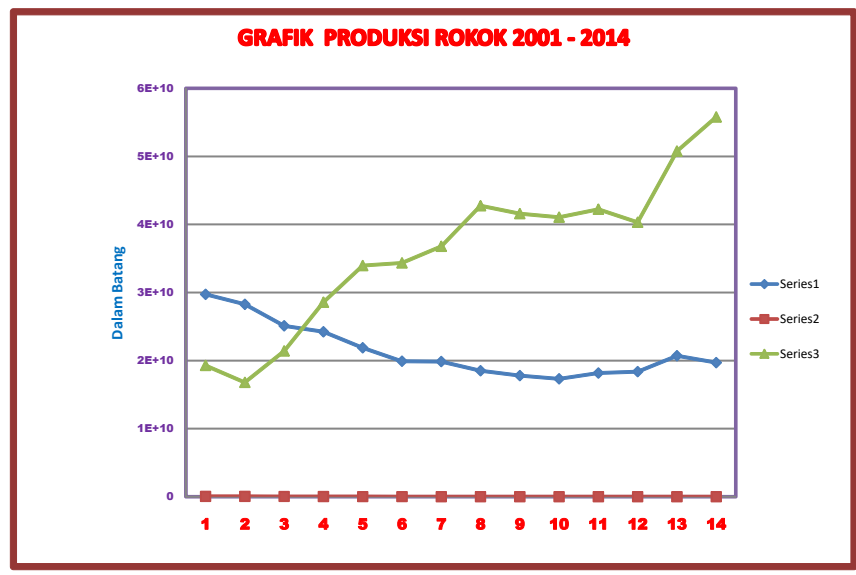

Series Produksi Sigaret Kretek Tangan (SKT)

Series Produksi Klobot (KLB)

Series Produksi Sigaret Kretek Mesin (SKM)

Graphic 1: Kretek Production in Kudus from 2001 to $2014^{7}$

Based on the graphic given above, it can be seen that the production rate of Hand-Rolled Kretek are leading to downfall where there is a steady decrease over time since 2001 which makes the production rate are now on the 20 Million on 2014 and on the contrary to the Machine-Rolled Kretek that has a steady increase since 2001 .

\section{b. A description of the characteristics and qualities that differentiate}

Kretek is an original product of Indonesia; it has the characteristics that distinguish it from cigarettes in general because Kretek has been through the acculturation process of cigarettes brought by foreign nation into one of indispensable nation culture that can be seen regarding both, history, a method of manufacture, production control even marketing techniques. The

\footnotetext{
${ }^{7}$ Data Obtained from Persatuan Perusahaan Rokok Kudus in November 2015
} 
difference of Kretek with Conventional cigarettes, in general, can be seen in the table below:

Table 2

The Difference Of Conventional Cigarette To Hand-Rolled Kretek Cigarette

\begin{tabular}{|c|c|c|}
\hline Differentiator & $\begin{array}{l}\text { Conventional } \\
\text { Cigarette }\end{array}$ & Kretek Cigarette \\
\hline Composition & Tobacco & $\begin{array}{l}\text { Tobacco (mix from many } \\
\text { variants), Clove, some are } \\
\text { mixed with secret kretek } \\
\text { sauce. }\end{array}$ \\
\hline Origin & United States & Indonesia (kudus) \\
\hline Tar Content & Less & $\begin{array}{l}\text { Higher Because it contains } \\
\text { Eugenol although it is not } \\
\text { carcinogenic. }\end{array}$ \\
\hline Efficacy & $\begin{array}{ll}\text { Improve } & \text { Brain } \\
\text { Performance } & \end{array}$ & $\begin{array}{l}\text { Improve brain } \\
\text { performance, treat asthma, } \\
\text { warm up the body. }\end{array}$ \\
\hline $\begin{array}{l}\text { Consumption } \\
\text { Tradition }\end{array}$ & $\begin{array}{l}\text { As a traditional } \\
\text { ceremony tool of } \\
\text { native American } \\
\text { where it is now } \\
\text { scarce. }\end{array}$ & $\begin{array}{l}\text { As a traditional ceremony } \\
\text { tool (rokok sajen) where it } \\
\text { can be found even in } \\
\text { modern age. }\end{array}$ \\
\hline Tradition in Creating & None & $\begin{array}{l}\text { There is an abon system } \\
\text { (cigarette roller carry out } \\
\text { at their work to their home } \\
\text { to make it sometimes with } \\
\text { their family) }\end{array}$ \\
\hline Flavor & $\begin{array}{l}\text { Less Variative as it } \\
\text { only contains one } \\
\text { ingredient }\end{array}$ & $\begin{array}{l}\text { More varied because of its } \\
\text { huge selection of } \\
\text { ingredients. }\end{array}$ \\
\hline
\end{tabular}

Source: Data Collection Analysis

Also if it is seen from the differences between Hand Rolled Kretek and Machine-Rolled Kretek, there are more differences, like how Hand-Roller Kretek Absorbs more labor and of course, creating a labor-oriented tradition like Abon, ${ }^{8}$ not to mention its unique shape where its smaller on the suction end making it as a natural filter. Kretek Cigarette classification are quite

\footnotetext{
${ }^{8}$ A tradition where the Roller (Labour who specialized in Rolling Kretek) bring the work to home to finish it. Data Obtained from PPRK Kudus in November 2015.
} 
complex because although it can be drawn that their difference with other conventional cigarettes is that Kretek is essentially a mixture of tobacco and cloves in general, and there are some people who are then given a special sauce and wrapped either with corn leaves, paper or tobacco dough, so it produces an unlimited combination either because of the combination of tobacco used, cloves, sauces or even wrappers used.

The complexity of Kretek or specifically hand-Rolled cigarette classification is also basically experienced by all handicraft products. Article 56 point (7) of Indonesian's Act No.20 year 2016 stipulates that registered Geographical Indication gets legal protection that lasts as long as the characteristics and qualities under which the protection of such geographical indications exists. It is incriminating the Geographical Indications product of craft and industry because its uniqueness lies in its creator/human. Although theoretically, handicraft can be a product of Geographical Indication, but unlike products that depend on natural factors such as Cilembu Yam, for example, which only grows in Pamulihan area, West Java, Sumedang where it is closely related to geographical condition, so that if the plant is planted on other soil, they will not produce such honey-flavor which is found in Cilembu-yam. Handicrafts and industrial products are products derived from the human intellectual property so it can be concluded that:

a. It does not have to stick with the territory.

b. The maker can create his product at will.

Why so? The handicrafts and industrial products in this case, such as carving furniture and Hand-rolled Cigarettes does not have to be fixed on Kudus or Jepara district only for its geographical indication product, or have to use materials from the same area because its uniqueness lies in their manufacturer/creator, and this will make quite difficult for the industry outside the area in question. The second point, because its uniqueness lies in the maker then it cannot rule out the possibilities that the product will continue to change afterward because of certain factors such as market demand. The two postulates revealed by the author above that states that handicrafts or industrial products are not fixed on one particular area and can be created at will by its author meaning that they are different from natural products so judging from the current regulation, it is quite difficult for it to be a geographical indication, but that does not mean that it can not get protection from intellectual property rights, especially geographical indications. Several points can justify this.

The product of handicraft and industry is closely related to the two postulates mentioned above, but it does not mean that the distinguishing 'characteristics' which underlie its protection as no intellectual property rights. Like Hand-Rolled Kretek Cigarettes that according to Sitepoe are different from conventional cigarettes regarding its conical/conical shape 
and flavor. Indonesian cigarettes have narrowed edges on one side that are used to inhale cigarette smoke and widening ends on the other side which is used as a burning place. This form is also considered to be a natural filter because the narrow cigarette sucking tip causes the smoke to be inhaled to be less and more durable than the cylindrical engine cigarette, and not to mention its flavor in which is the result of any combination of ingredients whether its tobacco, clove, sauce or even its wrappings.

Related to the two postulate expressed by the author in relation to Hand-Rolled Kretek Cigarettes which is the subject matter of this Article, then to support the authors' argument about whether or not the hand-rolled kretek cigarettes and, representing all industrial and handicraft product of geographical indication then the author would take to point an example of Carving Furniture Jepara. Furniture Carving Jepara is the only Indonesian's handicraft product that has become the product of geographical indication. But according to the research conducted by the author, the furniture carving of Jepara cannot be said as the result of "handicraft" because of its large scale of production ${ }^{9}$ so that it can be categorized that it is the result of industry because of the term of industrial or handicraft actually only refers to its scale of production and of course the amount of capital means that the product is categorized as handicraft industry product. ${ }^{10}$

Jepara carving furniture, as expressed by the authors previously, if seen from its carving style that expressed the characteristic/uniqueness of Jepara carving furniture then it means the carving does not have a sufficient characteristics enough to be called as "unique" as it can be seen from the books of Geographical Indications requirements of the Jepara carving furniture below : ${ }^{11}$

1. The plant pattern is the most widely used, described regarding patterns distillation, many composed with a garland pattern, or lunglungan pattern.

2. A clustered pattern like a fan and there is fruit pattern in an odd number; the group formed a triangular prism-like leaf pattern, and each leaf has three ends of stalks.

3. The direction and movement of plant patterns reveal the motion of balance to the left then to the right and so on.

\footnotetext{
${ }^{9}$ The last data obtained in 2006 where the number of production reached 55,765,736.12 with the monetary value of 111.842.200, 42 USD, Source Book of Geographical Indication Requirement of Furniture Carving of Jepara, 2010.

${ }^{10}$ Manufacturing \& Investment Around The World: An International Survey Of Factors Affecting Growth \& Performance, ISR Publications/Google Books, revised second edition, 2001.

${ }^{11}$ Geographical indication book of requirements of Jepara carving furniture, Jepara district government, 2010.
} 
4. Fractions on a leaf form a "beam," lines on a leaf. Leads from the petiole to the tip of the leaf.

5. The sculpture is conclave thin 6. Weak, or basic engraving is not too deep, but there are also carvings that are translucent.

6. The composition of engraving is generally symmetrical.

7. The pattern of animals commonly uses bird pattern as part of the composition of plant patterns.

The definition of the Jepara carving furniture is still too broad because it uses the word "generally," and "there are also" as stated in the points 6,7 and 8. The use of this words interprets the limitation of what Jepara carving furniture becomes ambiguous. The same was found in the System of Geographical Indications in India, which also recognizes the craft and industrial products as a geographical indication. From its system. It can be seen that Geographical Indications in the form of the Manufacture (Industrial) also has a characteristic which is also less significant such as Mysore Agarbathi (Incense), Coimbatore wet grinder (Wet grinding), Kannauj perfume (Perfume) and other crafts that also does not have a significant characteristic. ${ }^{12}$

\section{c. Natural factors and or human factor in which is a unity that gives influence to the quality or characteristics of the goods produced.}

The Discussion of Hand-Rolled Kretek Cigarettes will certainly relate to Kudus, a district in which is the smallest district in Central Java with an area of 42,516 Ha which is divided into nine districts. The Kudus district had a title as the town of Kretek as it is not without reason because Kretek, or specifically Hand-rolled Cigarettes were first found in Kudus. Kudus itself is also the central city of 4 major cities besides Kediri, Surabaya, and Malang which produces Hand-Rolled Kretek Cigarettes.

What makes the Kretek Hands industry in Kudus so fertile? It is because, given the less fertile soil types and narrow land area, the agricultural sector in Kudus does not develop like many other areas in Java. Therefore, like most other districts along the north coast of Java Island - the service, trade, and industry sectors are even more rapid in Kudus, even from the time of the Dutch colonial past. Soekisman (1995) noted that based on the historical data from the beginning of the 20th century, most farmersparticularly in the area of Kudus-- has changed their works to various factories that have sprung up there, ranging from fireworks factory, floor tiles and ceramics, ice processing and also kretek Cigarette whereas many

${ }^{12}$ Registered GI November 2015 In India, Http://IpIndia.Nic.In/GirIndia/, accessed on November 202015 
choose hand-rolled cigarettes as its friendly to small and mid-range Industries. $^{13}$

The Kretek Handmade Cigarettes industry, which then was developed in Kudus, certainly absorbed many skilled workers in hand-rolled kretek cigarettes from the selection of tobacco, clove, and sauce that is not arbitrary because it takes a lot of experience accumulated from generation to generation.

\section{Implications that may occur if Hand-Rolled Kretek Products In Kudus district can be Protected As Geographical Indications}

To find out how much implication that may occur if Hand-Rolled Kretek Became Geographical Indication Product of Handicrafts, it must then be analyzed first using Friedman's theory of legal system elements as follows:

When viewed regarding Substance Elements Of Legal System, although when viewed from the rules of what can be Geographical Indications Product, Hand-rolled Cigarettes meets, regarding regulation of the tobacco industry haven't been being seen any support. Regarding the substance itself, the Embryo of cigarette industry restraint including Hand-Rolled Kretek Cigarettes Starts from Law No. No. 36 the on 2009 of health in Article 113 which can be read as follows:

a. Safeguarding the use of substances containing addictive substances directed so as not to disrupt and endanger the health of individuals, families, communities, and the environment.

b. Addictive substances referred to in paragraph (1) include tobacco, containing tobacco products, solids, liquids, and gases that are addictive use can cause harm to themselves and the surrounding community.

c. The production, distribution, and use of materials containing addictive substances shall comply with the established standards and requirements.

The law is then further stipulated in Government Regulation no. 109 of 2012 as its operational regulation which later became the spearhead of anti-smoking activities. ${ }^{14}$

It is enough to hit hard the cigarette industry, especially the HandRolled Kretek Cigarette industry in the provision of tar threshold in cigarettes. This provision is incriminating Kretek Cigarettes industry as

\footnotetext{
${ }^{13}$ Roem Topatimasang, Kretek Kajian Ekonomi; Jogjakarta: Indonesia Berdikari, 2010, p. 68.

${ }^{14}$ PP No. 109 Year 2012 is according to the author's opinion is an extension of the FCTC (Framework Convention on Tobacco Control) because many rules are more or less a copy of the FCTC to suppress the cigarette industry. Where the most affected is the Small and Medium Cigarette Industry. Aditia Bagus Santoso, Analisis Hukum Dampak Belum diratifikasi kerangka kerja konvensi pengendalian tembakau (Framework Convention on Tobacco Control) Bagi Indonesia, Fiat Justisia Jurnal Ilmu Hukum, 8(4), (2014). p. 691.
} 
eugenol, the levels contained in the cloves are also categorized as tar despite not having a carcinogenic substance. Categorizing Eugenol as a harmful tar made Kretek Cigarettes in a cornered position and benefited the white cigarette industry that fully uses tobacco. This condition is very ironic because the existing rules seem to support white cigarette that does not contain Eugenol so that the tar content contained in it can still be controlled. The substance of the law issued by the legislature to curb the movement of Kretek Cigarettes in Indonesia makes other structure, particularly the executive bodies to enforce the regulations in which are cruel especially to low and mid-level industries which relies on its hand-rolled kretek, disregarding its deep-rooted culture in ours as The provisions in the Health Act also makes the ministry to compete and participate in the "anti-smoking campaign". ${ }^{15}$

This form of participation can be seen in the ministry of industry where For tobacco industry, under Article 4 points (3) ministry of industry regulation number 64 of 2014 are required to have a factory with an area of at least 200 square meters and are directly adjacent to the highway and be easily accessible. This provision is quite difficult for the cigarette industry, especially the hand-rolled kretek cigarette industry as most of them are a small industry and many of them are still not cooperating with large industries. The provision of this factory area is a continuation of the provisions of Article 3 paragraph (3) of Regulation of the Minister of Finance No.200/PMK.04/2008 previously. Rules of this finance ministry to make 93 cigarette factories in Kudus revoked its business license because they cannot meet the provisions of the factory area that has been mentioned. ${ }^{16}$

Regarding legal structure, the government institutions are divided into executive, judicial and legislative. About the potential of Hand Clove Cigarettes as Geographical Indications, it is certainly closely related to the role of government institutions, both executive, judicial and legislative in protecting hand-rolled kretek cigarettes.

Regarding executive and legislative, for example, the author will try to relate to the Kudus government. In an interview with Mr. Yosi from the subdivision of the Law of the District Government of Kudus, in relation to the provisions of Article 3 paragraph (3) of Regulation of the Minister of Finance No.200/PMK.04/2008 requiring cigarette entrepreneurs to have a

\footnotetext{
15 The world's anti-smoking campaign has been started since anti-smoking research as found by Robert and Rosalind about the dangers of smoking. Robert A. Levy And Rosalind B.Marimont, Lies, Damned Lies,\& 400,000 Smoking-Related Deaths, Journal, in Regulation 21(4), 1998.

${ }^{16} \mathrm{Http} / / /$ Kabar24.Bisnis.Com/Read/20120208/78/63266/Izin-Usaha-93-Pabrik-Rokok-Dicabut accessed on November 23, 2015.
} 
factory with a minimum area of 200 meters, Small entrepreneurs who are mostly home-based industries. In response, the Kudus regency replied by issuing the Regulation of Kudus regency No. 7 of 2011 on the environmental management of small tobacco industry (LIK IHT) and erecting cigarette industry meeting building and tar and nicotine testing service in Kudus District.

LIK IHT is a donation plant of Kudus government from DBHCHT (Tobacco excise tax revenue share) where ten plants are already available for rent at the cost of only 4 million rupiahs per year for a maximum of 5 years. The protection effort of the Kudus Regency government of Kretek Cigarette Industry has been enough evidence of co-operation of the legal structure in the protection of Handed Clove Cigarettes.

As for the second element: The Legal Structure, its work is not independent, it is related to each other both the legal culture and also affected from the element of legal substance which in this case is the extension of the hand of Law Number 36 Year 2009 on the health of Article 113 so that responsible government agencies such as director general of Duties and excise duty under the finance ministry, and the ministry of industry shall be obliged to continue the rule. Continued from now on interpreted to be restrictive as it is done by the ministry of industry or interpreted as not ruling out the rules parallel to it such as the protection of UMKM industry as did the government of Kudus Regency.

The third and final point of Friedman's theory is The Legal Culture. It is the views, customs, and behavior of the community on the norm values and expectations of the prevailing legal system, which means the legal culture is the climate of social thought about how the law is applied, violated and implemented. About the Culture of Hand-Rolled Kretek Cigarette Regulation, of course, the first thing that comes to mind is the public's negative view of smoking.

As previously mentioned, the Indonesian people are well aware of the anti-smoking campaign, supported by data from medical research that supports that cigarettes are "dangerous" so much that news like cigarettes produced by Pro-Cigarette researcher such as Divine Cigarette Nanotechnology research that prevents free radicals in the body and produces relatively little smoke from conventional Cigarettes isn't even heard of yet. ${ }^{17}$

The culture of the people who are already attached to this antismoking campaign coupled with the weakness of Hand-Rolled Kretek

17 Diskusi Divine Cigarette Rokok yang menyehatkan diakses pada: Http://Www.Kaskus.Co.Id/Thread/5128ef7e8027cf8b30000004/Diskusi-Divine-Cigarette--Rokok-Yang-Menyehatkan/1 date 01/09/2015. 
Cigarette Industry protection is the reason why the protection of HandRolled Cigarettes becomes an Urgency. ${ }^{18}$

About legal culture. Then the question arose, Are these two things related? Borrowing opinions from Lawrence M. Friedman on what is a Legal Culture:"...social Thought and social force which determines how law is used, avoided, or abused" ${ }^{19}$ it will be very tangent to chapter 56 verse (1) Points (a) where the product which may not be registered as a Geographical Indication Product of Handicraft it is contrary to laws, morality, religion, morality, and public order rules of morality, religion, morality, and public order are not separated from the first two points mentioned above.

Making Hand-Rolled Kretek Cigarettes as a product of Holy Geographical Indication is essentially the same as making Hand-Rolled Kretek Cigarettes as a mainstay product of Kudus District which means that the district government is obliged to preserve the knowledge of Hand-Rolled Kretek Cigarettes and support the hand-rolled Kretek Cigarette industry.

The act of preserving the knowledge of Hand-rolled Kretek Cigarettes has been done by the Kudus Government as can be seen from the establishment of the Kretek Museum of Kudus but about efforts to support the Hand-Rolled Kretek, Cigarette industry seems to be a difficult thing.

The form of support from the government of Kudus Regency is, of course, should be in the form of introducing their flagship product of HandRolled Kretek Cigarettes to the public and this will certainly become a polemic because the act of introducing Hand-Rolled Kretek Cigarettes to the people will collide directly with the provisions of Article 27 government regulation number 109 the Year 2012.

In response to this, the author tries to clash it with the provision of Geographical Indication. Within the rule of law which is the existence of the Hierarchy of Law. ${ }^{20}$ It is a strata of the rule of law applicable, and within the hierarchy, the Basic Law is in a higher stratum than the Law or the government regulation under it.

Government Regulation No. 109 on 2012 is equivalent to Government Regulation No. 51 on 2007 so when viewing the Act above it can be seen that Law No. 20 of 2016 regulates the substance that is addictive which later be described in Article 113 that addictive substances include tobacco

\footnotetext{
${ }^{18}$ Tia Zhalina, Improving Quality of Hand-Rolled Kretek Cigarettes (Skt) With Six Sigma Method (Case Study on PT DJARUM KUDUS-SKT BL 53), Jurnal Rekayasa dan Manajemen Sistem Industri, Universitas Brawijaya,Vol 1 No 2 Year 2013, Page 394. Mention That the hand-rolled Kretek cigarette production system is still so simple so that it has a higher production defect rate than cigarette machine. This certainly makes the competitiveness of hand-rolled cigarettes lower.

${ }^{19}$ Lawrence Friedman, American Law, London: W.W Norton \& Company, 1994, p. 6

${ }^{20}$ Bab III Pasal 7 Ayat (1) UU No 12 Tahun 2011 Tentang Pembentukan Peraturan Perundang Undangan
} 
products. Geographical indications are also similar; it is regulated by Law No. 20 of 2016 about the brand which is then regulated by Government Regulation No. 51 in 2007. But there are two things to note here.

First regarding equivalent rules. Health Law only gives authority to the rules below. In this case, government regulation No. 19 of 2012 need to be directed so it will not interfere and endanger the health of individuals, families, communities, and the environment. But in reality the rules contained in this government regulation regulate the authority to give limitation on ads relating to tobacco products (Over-Authority) so that if you see the rules that are above the strata of the Act Geographical Indication is superior because he regulated protection in the Law 202016 and its implementing regulation namely PP no 51 of 2007 which does not exceed the authority granted by the Law so that in the arrangement to introduce Kretek Hands Cigarette product to the community if Handed Clove Cigarettes become a product of Geographical Indication of Kudus Regency can still be allowed under the Act.

The second point that reinforces the explanation of the first point is the existing rule above the two Laws namely the Basic Law. In the Constitution, two Articles are supporting the existence of Hand-Rolled Kretek cigarette industry in Indonesia namely: Article 27 paragraph (2) where every citizen is entitled to work and livelihood that is suitable for humanity. And Article 32 paragraph (1) where the state is advancing the national culture of Indonesia in the midst of world civilization by ensuring the freedom of society in maintaining in the development of the value of its cultural values.

Article 27 paragraph (2) and Article 32 paragraph (1) of the Constitution may become embryo of Hand-Rolled Kretek Cigarette Protection as a product of Geographical Indication of Kudus. Article 27 paragraph (2) for example. Hand-Rolled Kretek Cigarettes Industry is one of the industries that absorb a lot of workforces therefore the labor that is in it should get proper protection so it should not be differentiated from other industries with rules such as Article 4 point (3) Regulation of the minister of industry number 64 of 2014 which obliged a factory with a minimum area of 200 square meters that incriminates small industries.

The provisions of Article 32 Paragraph (1) may become the basis of the efforts of the Kudus Regency government when the Hand-Rolled Kretek Cigarette becomes the product of the Geographical Indication of the Kudus District in the case of the preservation of traditional knowledge of HandRolled Kretek Cigarettes.

Article 27 paragraph (2) and Article 32 paragraph (1) of the Constitution mentioned by the author are not with the intention to defend the hand clove Cigarettes. The author in making this paper is trying to be 
objective because the facts in the rules are so. To be objective, On the contrary to the cigarette itself, there is a rule that supports it in the Basic Law, which can be seen in Article $28 \mathrm{H}$ paragraph (1) where every person has the rights to live a prosperous and spiritual life, to live, and to get a good and healthy living environment and is entitled to receive services health.

\section{d. Conclusion}

The conclusion of this research is that Hand-Rolled Kretek Cigarettes can become Geographical Indication Product of Handicraft because it is in accordance with the requirement in terms of history, distinguishing potential, and sufficient potential of economic and its in accordance with the rules of the invitation, morality, religion and public order required by Law No. 20 on 2016 and in its development may also be a Geographical Indication of national or even Indonesian Cultural Heritage since it was found in Kudus then it has spread to all over Indonesia.

Hand-Rolled Kretek Cigarette Protection as Product of Geographical Indication of Kudus District is an urgency to protect the hand-rolled Kretek Cigarette industry from foreign hands and to protect small and medium kretek industry that relies heavily on Hand-Rolled Kretek Cigarette Industry which is the backbone of the population not only in Kudus alone but also in Indonesia.

\section{Bibliography}

\section{A. Books}

Persyaratan Indikasi Geografis Meubel Ukir Jepara. (2010).

Persyaratan Indikasi Geografis Ubi Madu Cilembu. (2010). Sumedang.

Clark, G.C. (1989). "Comparison Of The Inhalation Toxicity Of Kretek (Clove Cigarette) Smoke With That Of American Cigarette Smoke. I. One Day Exposure". Archives Of Toxicology.

Colby, Lauren. Translated by Ronny Hendrawan. (2014). In Defense Of Smokers. Jakarta: Indonesia Berdikari.

Erikson, Michael. (2015). The Tobacco Atlas Fifth Edition. Georgia: American Cancer Society.

Friedman, Lawrence. (1994). American Law. London: W.W Norton \& Company.

Hadari Nawawi and Mimi Martini. (1994). Yogyakarta: Penelitian Terapan. Hutapea, Ronald. (2013). Why Rokok? Tembakau Dan Peradaban Manusia. Jakarta: Bee Media. 
Kesowo, Bambang. (2007). Posisi Dan Arti Penting KI Dalam Perdagangan Internasional. Jakarta: Citra.

Lubis, Efriadi. (2009). Perlindungan Dan Pemanfaatan Sumber Daya Genetik Berdasarkan Penerapan Konsep Sovereign Right Dan Kekayaan Intelektual. Bandung: Alumni.

Manufacturing \& Investment Around The World: An International Survey Of Factors Affecting Growth \& Performance. (2001). ISR Publications/Google Books. Revised second edition.

Posner, Richard. In the Sanders, Anthony, Posner, Hayek \& The Economic Analysis Of Law Paper. (2003).Virginia: George Mason University.

Sitepoe, Mangku. (2000). Kekhususan Rokok Indonesia. Jakarta: Grasindo

Topatimasang, Roem. (2010). Kretek Kajian Ekonomi. Jogjakarta: Indonesia Berdikari.

Trum Hunter, Beatrice, Indonesian Translated by Brahm Udumbara. (2004) Udara Dan Kesehatan Anda, Udara Bersih Sangat Penting Bagi Kesehatan Anda. Jakarta: Buana Ilmu Populer

\section{B. Journal and Article}

Aditia Bagus Santoso, "Analisis Hukum Dampak Belum diratifikasi kerangka kerja konvensi pengendalian tembakau (Framework Convention on Tobacco Control) Bagi Indonesia”, Fiat Justisia Jurnal Ilmu Hukum, 8(4), Oktober-Desember 2014.

Badrudin, Pengetahuan dan Keterampilan Membuat Kretek Tangan sebagai Warisan Budaya Tak Bendawi, Academic Paper, 2016.

Edi Atmadja, Article, Hukum Sebagai Sarana Rekayasa Sosial, Radar Lampung, 30 Mei 2012.

Robert A. Levy And Rosalind B.Marimont, Lies, Damned Lies, \& 400,000 Smoking-Related Deaths, Journal in Regulation Magazine, 21(4),1998

Tia Zhalina, "Peningkatan Kualitas Rokok Sigaret Kretek Tangan (Skt) Dengan Metode Six Sigma (Studi kasus pada PT DJARUM KUDUSSKT BL 53)", Jurnal Rekayasa dan Manajemen Sistem Industri, Universitas Brawijaya, 1(2), 2013.

\section{Legislations}

Framework Convention On Tobacco Control, WHO, 2003.

Republic of Indonesia Law No. 20 on 2016 of Brands and Geographical Indications 
Geographical Indications of Goods (Registration And Protection) Law, 1995. India.

Government Regulation No.109 on 2012 of Safety of Materials Containing Addictive Substances in the Form of Tobacco Products for Health

\section{World Wide Web}

http://Www.Sampoerna.Com/Id_Id/Tobacco_Regulation/Pages/Tobacco_Ta xation_System_In_Indonesia.Aspx accessed on 14/08/2015

Melissa Brockley, TED Case Studies Number760, 2004 Pada Http://wwwl.American.Edu/Ted/Turkish-Tobacco.Html, accessed on $14 / 08 / 2015$.

http://www.Pmi.Com/Eng/Our_Products/Pages/Our_Brands.Aspx accessed on, 24 November 2015

Registered GI November 2015 In India, Http://IpIndia.Nic.In/GirIndia/, accessed on 20 November 2015

http://Kabar24.Bisnis.Com/Read/20120208/78/63266/Izin-Usaha-93-PabrikRokok-Dicabut Diakses Pada 23 November 2016.

http://Health.Kompas.Com/Read/2015/06/03/110000223/Jumlah.Perokok.In donesia.10.Kali.Lipat.Penduduk.Singapura accessed on 24 November 2016.

http://bolehmerokok.com/mengkonsumsi-kretek-tangan-menjagapenghidupan-banyak-orang/ date accessed 11/20/2017 